\title{
Coetzee's Disgrace: Rape and Escape connection to Bangladeshi perspectives
}

\section{Ms. Mahbuba Shoukot}

Ex IB Educator (Abdul Kadir Molla International School),

B.A in English Literature (AIUB), Post-Graduation

Diploma in International Relations (University of Dhaka).

Email: dina.bangladesh@gmail.com

\begin{abstract}
J.M Coetzee's Disgrace plot and the Bangladeshi Scenarios are mostly similar; especially in gender discrimination, though the situations and structure of society differ. Surprisingly, this makes me pretty much thoughtful the variances do not make any changes. Gender blindness is everywhere, whether in South Africa or Bangladesh. Women are always the scapegoat by society, religion ethnicity, norms, and rites. They always face violence or hatred in different folds. The essay conveys the forcible sex violations that happened in the novel. The story portrays the two male protagonists who are parallel in the antagonist role as well. Women's roles are used here to show how men prudently play dice to gain power and abduct a woman. Escape from the crime is the easiest way to build a new way out under the male chauvinist regulations.
\end{abstract}

KEYWORDS: Sexual harassment, Justice, Benefactor, gender discrimination.

\section{Introduction}

Rape and sexual harassment have become the most used vocabulary in this age. It is so visible everywhere, like social media, printed media, and so on. I want to say rape is not a fact that happened in this era; we have learned about it from the very beginning. In Greek mythology, God Zeus was noted with the holy act, even though in Hindu Puran. Woman's bodies are always deliberated as a product of lust. When the heinous molestation occurred, women got back to nature and reformed their identity. It has been illustrated in mythology God Apollo when he tried to assault any lady, she became a laurel tree by magic. Besides, after the sexual molestations, when she became expected, then the woman faces new reformation. She gave birth to another warrior and build a new civilization. (Humayun) What dramatic solutions have we learned!

Nowadays, women cannot do any magic or spell; nature also refuses to save them and reform them. So, as consequences, they need to bear the trauma of the rape. Rape is a severe kind of defamation by society. The victim feels more secured to be dead. Death is more preferable than to face all. In disgrace, the author trying to anticipate the rape and post-apartheid stigma. However, he tried to mirror the issue only based on post-apartheid penalties and racism. Gender discrimination also a dominant feature here. Molestation is anathema in any society, but the point is always women get victimized. In disgrace, whether black or white woman only they suffered, male-like David or Petrus showed possession of power and destabilized the woman power.
J.M Coetzee, a South African novelist, won a novel for English Literature's contribution. He writes the novel Disgrace to emphasize the post-apartheid significances through the family with the national interest. He attributes racism, gender role, violence between contrasting regions, and hatred between the black and white people. The story depicts the juxtaposition among the characters. Rape or forcible violation is a vital issue in this novel. The matter related to justice and retributions, hatred, and confession as well. The novel starts with the name Disgrace, which means shame or dishonor with the rape of the two women, symbolizes the death of dogs as a sign of exploitation. It also portrays law enforcement during the post-apartheid time.

\section{Objectives}

The paper is based on the present Bangladeshi context and the similarity between the novel Disgrace. Rape and forcible molestation is not a new story for society, it contains the resemblance of the time and nothing has been changed, though we are in the modern era.

\section{Literature Review}

Rape or sexual harassment is considered an aggressive movement in Gender Violence. It is a very awe-inspiring experience for the women, developed country women also facing the act severely which is surprising, Cassandra Wilson and Noreen Connell utters several consequences in their book "Rape: The First Sourcebook for Women" 
"Rape is an issue that didn't arise because feminist leaders decided it was 'the issue' or because it was a designated topic on a consciousness-raising list. Instead, it became an issue when women began to compare their experiences and realized sexual assault was common." (C. .. Wilson)

The instrumental theory of rape, propounded by Susan Brown miller in Against Our Will, argues that" men rape because their penises possess the objective capacity to be weapons, tools, and instruments of torture". Susan Brown Miller represents this view when she states in her influential 1975 book, Against Our Will: Men, Women, and Rape, that "in terms of human anatomy the possibility of forcible intercourse incontrovertibly exists. This single factor may have been sufficient to have caused the creation of a male ideology of rape. When men discovered that they could rape, they proceeded to do it.

Post structuralism and the feminist view entitle the Raped woman body as the symbol of lust and aggression. Sharon Marcus utter the fact in "Fighting Bodies, Fighting Words: A Theory and Politics of Rape Prevention"

"The undesirable consequences of the slide into a relativism that results from too facile a conflation of world and text is particularly evident when feminist concerns are taken as a starting point.

Rape, domestic violence, and sexual harassment... are not fictions or figurations that admit the free play of signification. The victim's account of these experiences is not simply an arbitrary imposition of a purely fictive meaning on an otherwise meaningless reality. A victim's knowledge of the event may not be exhaustive;

. . But it would be premature to conclude from the incompleteness of the victim's account that all other accounts (the assailant's, defense attorneys, character witnesses' for the defendant) are equally valid or that there are no objective grounds on which to distinguish between truth and falsity in divergent interpretations" (Hawkesworth)

\section{Methodology}

The present study collected relevant information from secondary and primary sources. The researcher also accessed different online sources like (scholarly paper, books, newspaper reports, etc.) The researcher conceptualizes the relevant framework from Bangladesh and develops the main ideas to further inquiry.

\section{Finding and discussions}

The main protagonist David Lurie, a professor, works at the University of cape town. The characteristics of Byron influenced him. Byronic heroes are leading erotic life. Their characteristics are different from the traditional hero.
David 52-year-old man who divorced twice, but still, his body is seeking a beautiful woman. To fulfill his empty soul, he wanted to write the tunes and origin of songs. He wants to write: "Meditation on the love between the sexes in the form of a chamber opera." (pg. 4, lines 14, disgrace). As he was an unhappy soul, always finds happiness through the woman's body, though he was a scholar. Sometimes he hummed the Chorus of Oedipus with great passion and believed "Call no man happy until he is dead."(Pg.2, Chapter 1, Disgrace). He is the portray of the masculine and proud fellow of white supremacy.

He finds sex as like as a totem; it can be a snake. He imagines Soraya, a prostitute girl like a totem, absorbed, dry but hot. Soraya, who charges 400 dollars for ninety minutes, where David finds physical pleasure and tried to teach her the irony of life. However, he does not like her sticky makeup and ordered her to wash it. She obeyed. When she leaves, he tried to find her through the detective. It is not for his love, and it was the selfish male ego that could not let a woman go of her own will. The scenario expresses when he calls her, and she denied identifying him and demanding not to call her again. Then his male ego uttered himself and surprised him. "Demand. She Means Command "(pg-10, Chapter 1, Disgrace). The male chauvinist mind could not take a denial. Besides, she was a prostitute. Again he feels like a predator back home from the vixen's den with an empty hand." A shadow of envy passes over him" (pg.10, chapter 1, disgrace)

As David found himself a predator, it is obvious it will find the next vixen for a new journey. Here comes the new climax Ms. Melanie who was his student, and he felt attracted to her. The girl was shy and introverted. He tried to captivate her with his gender-biased confession. The depth of gender blindness was expressed with the statements, "Woman's beauty does not belong to her alone, it is the part of the bounty; she brings into the world. She has a duty to share it." (J. .. Coetzee)

His instincts and power predominated David. He tried to seduce Melanie with his spoken words, which are old fashioned and very typical. Praising her with her smile and physical beauty. It depicts the primitive process to tumble one lady. As he pronounced, "From fairest creatures we desire increase', he says, 'that thereby beauty's rose might never die.' Not at good move. Her smile loses its playful, mobile quality. The pentameter, whose cadence once served so well to oil the serpent's word, now only strange. He has become a teacher again, man of the book, guardian of the culture hoard. She puts down her cup. I must leave; I expected." (Coetzee, Disgrace) we can relate the essay with feminism, though feminism has started with sisterhood, unity, and equality. Feminism is diversified in two ways, black feminism, and white feminism. A black feminist believes that white woman is unable to understand the pathos and woes of black and third world women. 
Western structuralism identifies the third woman as illiterate, naïve, ahistorical in the imperialistic society. C. Talpade Mohanty writes, "Third world women" in terms of the underdevelopment, oppressive traditions, high illiteracy, rural and urban poverty, religious, fanaticism, and "overpopulation" of particular Asian, African, Middle, Eastern, and Latin American countries. Corresponding analyses of "matriarchal" black women on welfare, "illiterate" Chicana farmworkers, and "docile" Asian domestic workers also abound in the context of the U.S. besides being normed on a white, Western (read progressive/modern)/On-Western (read backward/traditional) hierarchy, these analyses freeze/third world women in time, space, and history." (Cartographies of Struggle, Third woman, and social category). (C. T. Mohanty)

Melanie was a black girl who was abused by a white man and subjugated by society. Though the incident occurred post-apartheid, it was always centralized by slavery. Also, third-world women were manipulated by the colonialist, capitalist, and later religious ethnicity. At that time discussion on third world women was very much monolithic, static. Mohanty acclaimed one fact the feminism or states of third world woman it can be defined with one reason, it depends on history, social context, history, religious ethnicity. like in 1979 Iranian politicization causes national revolution, and in post-1979 domestications of feminist demands and ideologies of womanhood were measured by the Islamic fundamentalists state. (Tohidi) In 1979 , the rate of rape was dramatically high in the US, because in gender politics like racism it was treated as a slice of agitation. Black Panther leader A. cleaver adopts new techniques for the black follower to exploit white women like physical abuse or verbal abusements. (Azad) [secondary The porter1986,218] . Moreover, During the British raj, forcible sexual relations was rationalized by the colonial rule. The consolidation of bureaucratic masculinity was not controlled. In 1971, the Bangladeshi woman suffered war rape by Pakistani militant groups.

David as a white man, stereotypical comments for the woman and thoughts showed his passions for the girl's body and lust for sex. He molested Melanie without her consent though she was silent, breathless, and not yelling to save herself from him. "Since the relationship of a woman of color to the white man is usually meditated by state institutions, they can never define feminist politics without account for the mediations. (T. .. Mohanty) . Whatever the white man David or Brown man Karim Mia molestation happened to legalize male authority and expected desire. After the act, if they are in process of justice they try to generalize the fact victim and he has affair or relationships. As we can see David told Hakim He had affair with Melanie. It is so collective issue in rape because it rationalizes the heinous act and allows society to radicalize the girl. In the poem "I Ain't the Right Kind of Feminist"
First off I'm too confused

Secondly, you know my blackness envelops me

Thirdly my articulateness fails me

When the marching feminists come by

I walk with them for a while

And then I trip over pebbles I didn't see

My sexist heels are probably too high

I'm stuck in the sidewalk cracks

Oh where Oh where has my feminism gone .... (Cheryl L. West,16. Breaking wave)

After the scandalous turn, when the judgment has been started, he was so valiant and confident. He answered their questions so peacefully and had no guilt or anything even though he did not want to allow someone for advocacy. Whatever he has done, no regrets, no guilt feeling. He just generated his statement. He started the role full of power and confidence and left the place. He returned to his daughter Lucy. I think the Judgement could not go so long because Isaac's family was not there with substantial evidence. A black, maltreated girl going for the long run was tough for herself and her family as well. So, David just lost his job and left the place. Here the author did not show us the raped girl's agony and woes. He runs stream -roller in the racism, post-apartheid dichotomy. Also, Melanie or any Brown girl from Bangladesh it is every day's cup of tea for us, victims' family feel awe-inspired for the security and defamation. Most of the cases closed due to the reason. On average 4 girls being raped every day in pandemic situations, 3 are committing suicide for defamation and injustice. One can survive but her trauma could not be described in a words. 632 Rape case identified by the Ain Salish Kendra ( Human Rights organizations. (Rabbi)

David's life was revolving around himself. He was a white man with a job, life, women, and power. Especially in South Africa after apartheid, he finds himself better than everyone else in white men. These books often showed definitive statements that reveal his life just spawning himself and the inner urge. His daughter

Lucy was being acquainted with that. As she said,

\section{“[...] David, I can't run my life according to whether or not you like what I do. Not any}

more. You behave as if everything I do is part of the story of your life. You are the

the main character, I am a minor character who doesn't make an appearance until halfway

through. Well, contrary to what you think, people are not divided into major and minor.

I am not a minor. I have a life of my own, just as important to me as yours is to you,

and in my life, I am the one who makes the decisions." (Pg. 198, chapter 22, Disgrace) 
David wanted to abort the child because the child would not be an excellent decision to have the child without the sense of father. Here Lucy was courageous about her decision. Being a woman, it is so apparent that motherly instinct from birth. Here she raises her voice to keep the baby. She uttered the statement so discreetly,

"I am a woman, David. Do you think I hate child? Should I choose against the child because of who its father is? \{....\} David: And your mind is made up?"

Lucy: Yes.” (p. 198, chapter-22, Disgrace)

Here again, arisen issue of white feminism and black feminism, Lucy as a white woman has the right to choose her will, but for the color woman it is prohibited and it's like putting the cart before the horse.

"The arena of reproductive rights, because of the race- and class-based history of population control and sterilization abuse, women of color have an ambivalent relation to the "abortion rights" platform. For poor women of color, the notion of a "woman's right to choose" to bear children has always been mediated by. a coercive, racist state." (T. .. Mohanty).

For the colored woman based on a social context like Bangladesh, it is impossible, and against Islam's fundamental rules. Though partially Lucy also depicts the motherly instinct of what is universal for the woman, the bravery she showed to the decision prevails as a white civilized woman. He confessed to his daughter whatever her decisions; he will stand beside her. At that moment, he was shaken by the situations, reconciliation of his sin. As David had started his life with pomp and power, but the circumstances made him taken aback and weaken. He could not control his desire for a woman. We can remember his utterance with Byron, "He went to Italy to escape a scandal, and settled there. Settled down." (Coetzee 15).

He also tried to emphasize his desire for his daughter. Sometimes he compares himself to a dog. Dog plays here a symbolical role to the characters.

\section{"[...] when we were still living in Kenilworth, the people next door had a dog, a golden}

retriever [...] 'It was a male. Whenever there was a bitch in the vicinity, it would get

excited and unmanageable, and with Pavlovian regularity, the owners would beat it.
This went on until the poor dog did not know what to do. At the smell of a bitch it wouldchase around the garden with its ears flat and its tail between its legs, whining, trying tohide.' [...] A dog will accept the justice of that: a beating for a chewing. But desire isanother story. No animal will accept the justice of being punished for following itsinstincts." (Coetzee 89-90)

Bangladeshi Patriarchy society always suppressed the voice whether it man or woman. The way David open up himself to his daughter it is quite impossible for our society. To talk about sexuality with anyone with proper freedom considered the one shameless and out of norms. Though society and religion named it a very personal and hidden treasure. Only this talk is not gendered biased in Bangladesh. So, here white patriarchy can be more fruitful in relations and powerful with the bold voice. Father or Husband played as sovereign in the family. Chanayakka, a Hindu philosopher forbid the man, never expresses your feelings or experiences with the female; especially with your legitimate partner. Another very important picture of white society, patriarchy can be more sensible and responsible for his loved ones. Whereas in Bangladesh raped victim girl is like a burden to the father and family, he could not support her or throw her. the terrific moral dilemma they faced and struggled. If the girl died, he might be lost in deep pathos but at least social dignity and reputations saved. No more teaser or peer pressure. Women somehow forcefully lost her chastity, and she died with her self-esteem. Wow! what a peace! She recognized as Swati (Hindu Puran described the holy woman who jumped in the fire to prove her chastity) by society.

Another male chauvinist fact we can see here through the character Bev Shaw, a little woman with freckles. According to her physical appearance, it is surprising to the readers that David had intercourse with her. When David first met her, he simplifies her with her physical appearance. This is the way to undermine the woman with her somatic appearance but need her to accomplish his desire.

\section{"[...] a dumpy, bustling little woman with black freckles, close-cropped, wiry hair, and \\ no neck. He does not like women who make no effort to be attractive." (J. .. Coetzee, Disgrace)}

The similarity between David and the colored man that when he feels his desires it's doesn't mean she must have been very attractive with a slender figure. The salient fact to possess power over the woman. A man is like a hunter, sex is a pang of hunger when it comes just to jump. In Bangladesh several surveys have come black complexion, a fatty, old woman and statutory rape occurred every single day. They have no different taste bud or classicism in that sense. After meeting Lucy, David funded the body change of his daughter and exclaimed. What a nice girl! He did not leave any chance to watch his daughter and her body. 
Petrus, Another remarkable male protagonist in this novel. He worked on Lucy's farm and looked after her dogs. Petrus, the man whose heart is full of outrages and hatred for the whites. He introduced himself as a "Dog man" to David. He invited them into his house but showed no mercy to mock him as well. He said, 'God moves in Mysterious ways, David" (pg. 127, chapter 15, Disgrace). Petrus here symbolizes the figure of a black African whose hatred and fury stated in his every dialogue. "Lucy is our benefactor" (pg. 129, chapter15, disgrace). Petrus is the dominating figure who takes the opportunity by deceiving people. Most of the time scapegoat will be the female figure. This kind of opportunist create crime scenes and victimized the adolescent with fraud. Rape by deception and corrective rape occurred in Bangladesh to violate gender roles.

Petrus was very much cunning. He planned all those incidents, and his ideas were far-fetching, which is beneficial to his future. Lucy's child will be inherent in all her property, and through this process, he could change his status in this society. His status has promoted Dog Man to the caretaker of the property. Petrus was carefully careless about the rape incidents that happened with Lucy. He acted as it Should happen for the necessities. In that sense, David and Petrus both played the role of exaggerating their power for their own will. Petrus was less influential than David when they met. However, his atrocities and wish for power made him do the plan. He firmly believed that sex makes a woman pathetic and a male more powerful. As from black territory, it was his savage answer to the white woman.

\section{"I think I am their territory. They have marked me. They will come back for me.}

\section{[...] Hatred ...When it comes to men and sex, David, nothing surprises me anymore. Maybe}

for men hating the woman makes sex more exciting. You are a man, you ought to know." (J. Coetzee, Disgrace)

When some of the black boys raped Lucy and locked David in the bathroom, the scenario was horrible. They also tortured David and tried to burn him. The attackers were relatives of Petrus, and he was stoic about the situation. Instead, he was trying to wrap the issue, and it was just a mistake. Lucy was shattered and mentally lost her will to move or talk. Even she talked with her dad by his Name. Lucy was the representative of that kind of woman who always tries to make herself reason of any curse. She decided to keep the baby as the testimony of the apartheid clang. Alternatively, might be she tried to feel the agony of the black girl Melanie Isaac. She thought it would be justice for the injustice that occurred to the black people, or she only thinks about the black girl. Petrus, the protector of super patriotism, had already decided the child would be a baby boy. Petrus Intervenes,
"The baby is coming in October; we hope it will be a boy. Always it is the best First one is a boy.

Then he can show his sister's- show them to Behave. The girls are very expensive" (M)

Rape and after the escape is a very detectable concern in this novel. First, David somehow escapes from the misdeed he had done. After the same things repeated to him, though he was not the victim. The victim was his daughter. Though the end of the story stated that God plays his own game, readers must murmur in their mind sin will in your ways or karma come. However, the thing is, why always the woman should be the victim? If Lucy is facing the trauma of rape or sexual assault for her father's karma. What would her fault? It is the burning question to all the readers. Justice and vengeance, actually what? Is it done by God or by male chauvinist aspects?

Lucy was very much thoughtful after her sexual molestation. She was trying to find the reason and rectify it with its reason. A very sensible woman who wants to be a human being and trust nature's retribution. I think it will be a question to all-female when they encountered forcible sexual maltreatment, they observed the force of hunger where did it come from? The hatred and barbarities!

\section{She asked herself, \\ "It was so personal, she says \\ It was done with such personal hatred. \\ That was stunned me more than anything. The rest was... expected. \\ But why did they hate me so? I had never set eyes on them?" (J.

$$
\text { .. Coetzee, Disgrace) }
$$

She was not known about the pseudo power game of the male-dominated society. The author also displayed to us the post-apartheid muddle and the male desire. He somehow missed the irreconcilable male difference and woman malice. Though David and Petrus have a different motive to gain power, one is looking for materialistic stability by using Lucy, and David to fulfill his desire. Whatever distinguishes their mottos, basic is achieving the power and defaming the women stand.

\section{Rape and Escape: Bangladeshi Context}

Now talk of the town is recently one girl is being raped by the gang in front of her husband in Sylhet at MC college. 6 peoples accused of the act, they are heading the leading party of Bangladesh. (Chowdhury) This is the irony of the hegemony of the patriarchy one man could not save his spouse from another man. Similarly, David Could not save his daughter from gang rape as well. From the eye of the Ancient Bible to Capitalist, it is assimilated that Rape is considered as theft or robbery because a woman is a property of a man. 
So when a female is raped by a man that means he is stealing another man's asset. (Humayn). What a sarcastic fact! Nevertheless, in our country, including male domination, religious fatwa, or norms also violating the savage act. Rapists are roaming freely everywhere; law enforcement rarely can take them under penalty. Finally, in a someway woman stands as the main culprit. Society or court asked them an unlawful questionnaire that is more unbearable than the rape. Cleric thoughts Rape can be stopped by wrapping the woman. Wrapped them from head to toe, her body must not be seen. However, there is no iron box for the male to control their phallus. What funny logic? As if a woman leads every problem, captivate themselves might solve sexual molestation magically. The question is, what about the small girl raped by the adults; whose age is just 4 to 12 . Even though in their puberty time, they need to cover themselves. Is this the only solution to save themselves from predators? According to Suzann griffin, she never free from the fear of being raped" (The porter,1986,221). In Bangladesh, every woman is thinking like Suzan Griffin right now. Only parda or covering women cannot help them to be safe. It requires to be more sensitivity to the woman and their rights. It does not mean whenever one sees a woman, their masculinity arouses and just jumps over the female body to satisfy one's yearning. Again, come to the same analysis, which psychoanalytical mind tends to do that rape or show one's muscle to the woman? Sexual harassment is one kind of perversion or hatred. The rage that leads him to do. In the present age, women are reaching their goal, they can do any work. The woman is leading the nations governing the country. This is also the reason to show their vague hegemony to the woman. So cheap, isn't it?

David never is punished; his silent apology never be sent to Soraya and Melanie publicly. Tonny, Salma thousands of rape survivors of Bangladesh did not get any justice. The most legalized and famed punishment for rape in Bangladesh, for the sake of Islam, arrange a marriage between them, rape survivors, and rapists. In rural areas substantially, shalish or meeting by village communities find the phenomenal judgment. Last two years around 50 marriages took place with Rapist. (Islam) . "If a rape victim is forced to marry her tormentor she will suffer from a sense of helplessness and frustration throughout her life silently," said Ayesha Khanam, secretary of the Bangladesh Women's Council. Though the conservative Muslim Society finds the way the survivor and his family, become unmarriageable. In Bangladeshi Law "the law does not permit forced marriage between a rape victim and the rapist," said advocate Abdullah Abu of the Dhaka Bar. "The arbitration by the village leaders to compel a rape victim to marry her rapist is illegal. "Largely, 90 percent rapist is acquitted from the court due to a lack of evidence and use of legal dodges. Most of the cases are pending in the lower court. Like Bangladesh Petrus also want that Lucy should choose one to marry from the rapists.

\section{Conclusion}

White feminism, black feminism, or whatever the Brown feminism everywhere Women is the victim of the society Wherever in Bangladesh or South Africa. By comparing with any developed countries or third world women; their fate and circumstances all are the same in a different wrap. Today at the age of modern advancement we cannot think over it, still, gender equality is a struggle to the world. Many organizations are working to overcome it but our thoughts, ideology, male perversion of mind stands still same. May west satirizes "How ridiculous the men I have ever met want to save me! (West, 1986, p.218) Though David changed himself after the molestation of Lucy. However, what was Lucy's Fault? Why always mother nature picks woman's woes and chastity to teach the male predators? Who will anticipate the torment of Melanie, who will answer why Soraya is in prostitution? In other words, Petrus used Lucy and her chastity; made her scared finally achieved the power. It is manifested; "God moves in Mysterious ways", (Coetzee) only show his strength and fury on women. That is the real mystery.

\section{References}

1. Azad, Humayun. Nary. 4th ed., Agami Publisher, 2008, p. 6.

2. Chowdhury, Dwoha. MC College Rape: All Accused Arrested. The Daily Star, Dhaka, 2020, p. Back page, https://www.thedailystar.net/backpage/news/mc-college-rape-all-a ccused-arrested-1969745. Accessed 30 Sept 2020.

Coetzee, J.M. Disgrace. Vintage, 1999.

3. Fraize, Natalie et al. "Psychological History Of Women". Psychological History Of Women, 2011, https://psychistofwomen.umwblogs.org/. Accessed 2 Nov 2020.

4. Islam, Tabibul. RIGHTS-BANGLADESH: Rape Victims Married Off To Rapists. Inter Press Service News Agency, 2020, http://www.ipsnews.net/2003/06/rights-bangladesh-rape-victims-m arried-off-to-rapists. Accessed 7 Nov 2020.

5. Marcus, Sharon. "Fighting Bodies, Fighting Words: A Theory And Politics Of Rape Prevention". Columbia University Libraries, vol 18, 2013, p. 385., doi:https://doi.org/10.7916/D85B0BSG. Accessed 13 Mar 2013.

6. Mohanty, Chandra Talpade et al. THIRD WORLD WOMEN AND THE POLITICS OF FEMINISM.

7. INDIANA University Press BLOOMINGTON AND INDIANAPOLIS, 1991. 
8. Rabbi, Arifur Rahman. 4 Women Raped Every Day On Average 9. Wilson, Cassandra, and Noreen Connell. Rape: The First In Bangladesh Amid Covid-19 Pandemic. Dhaka Tribune, Dhaka, ${ }^{t}$ Sourcebook For Women. New American Publisher, 1974. 2020,

https://www.dhakatribune.com/bangladesh/2020/09/29/4-women-r

aped-every-day-on-average-during-coronavirus-pandemic.

Accessed 29 Sept 2020. 